\title{
ANALIZA PRIMJENE NASTAVNIH STRATEGIJA U VISOKOŠKOLSKOJ NASTAVI UMJETNIČKOG PODRUČJA
}

\author{
Antoaneta Radočaj-Jerković, Tihana Škojo \\ Akademija za umjetnost i kulturu u Osijeku, \\ Sveučilište J. J. Strossmayera u Osijeku, Hrvatska \\ antoaneta.radocaj-jerkovic@aukos.hr; tihana.skojo@aukos.hr
}

Primljeno: 31. 1. 2021.

U radu je prikazano istraživanje koje je bilo provedeno s ciljem analize primjene nastavnih strategija - metoda i postupaka, oblika rada na nastavi, kao i postupaka vrednovanja i ocjenjivanja studentskih postignuća - na jednom većinski umjetničkom visokom učilištu u sastavu javnog sveučilišta s područja Republike Hrvatske. Iz rezultata istraživanja razvidno je da je visokoobrazovna nastava oblikovana na suvremenim didaktičkim načelima s dominantnom paradigmom nastave usmjerene na studenta u kojoj se studente potiče na preuzimanje aktivne uloge u procesu učenja. Također, procesi poučavanja u umjetnosti su individualizirani, a praćenje rada i vrednovanje napretka studenata sustavno. Uočeno je da u umjetničkoj nastavi postoji određena terminološka nedosljednost u korištenju pojedinih didaktičkih pojmova jer je visokoškolska umjetnička nastava preuzela tradicionalnu didaktičku terminologiju prikladniju oblikovanju nastave u znanstvenom području. Kroz dobivene rezultate aktualizirana je potreba za pojmovnim redefiniranjem u kojemu bi se istaknule i objasnile specifičnosti koje proizlaze iz prirode umjetničkog procesa, a povezane su sa specifičnostima svakog pojedinog umjetničkog polja. Dobiveni rezultati otvaraju uvid u pojedine prednosti i nedostatke umjetničke visokoškolske nastave. Osim boljem razumijevanju umjetničke nastave, oni mogu doprinijeti i budućem sistematiziranju nastavnoga rada na umjetničkim fakultetima, osobito $u$ dijelu koji se odnosi na organizaciju $i$ vrednovanja kvalitete nastavnoga procesa.

Ključne riječi: nastavne strategije umjetničko-nastavnoga rada, nastavnici visokog učilišta, visokoškolska umjetnička nastava 


\section{Uvod}

Suvremena nastava na visokoobrazovnim institucijama izložena je stalnoj potrebi za inoviranjem i napredovanjem kako bi mogla odgovoriti na zahtjeve društva koje se ubrzano mijenja. Razvojne su tendencije u obrazovanju razvidne kroz iskazanu potrebu za permanentnim nadograđivanjem nastavničkih kompetencija, kao i kroz razvoj transferzalnih kompetencija te uvođenje suvremenih informacijskih tehnologija u nastavi (Strategija obrazovanja, znanosti i tehnologije, 2014; Strategija Sveučilišta Josipa Jurja Strossmayera u Osijeku, 2011). Kroz navedenu je usmjerenost prema unaprjeđivanju kvalitete nastave i stručnom usavršavanju nastavnika zamjetno da je poučavanje daleko odmaknulo od tradicionalnog prenošenja znanja na fakultetima koje je podrazumijevalo studente u ulozi pasivnih primatelja informacija. Tehničko-tehnološki napredak utjecao je na primjenu suvremenih organizacijskih rješenja, oblika i metoda, posebice uporabe medija koji nastavni proces čine intenzivnijim i učinkovitijim (Biggs, 2003; Novković Cvetković et al., 2018). Unaprjeđivanje obrazovanja, moderno poučavanje koje podrazumijeva aktivno učenje, iskazano je u Strategiji Europske komisije za 2020. godinu gdje se navodi potreba za fleksibilnim i inovativnim pristupima učenju i metodama te upućuje na mogućnosti i prednosti koje donose informacijsko-komunikacijske tehnologije (IKT) i druge nove tehnologije u smislu obogaćivanja poučavanja i poboljšanja doživljaja učenja. Recentna istraživanja iskazuju važnost upotrebe suvremene tehnologije u procesu odgoja i obrazovanja, naglašavajući značajan doprinos tehnologije u aktivnijem učenju, suradnji i zajedničkom učenju svih dionika nastavnog procesa te ističu poticanje kreativnosti i interaktivnosti, kao i veće mogućnosti vrednovanja znanja u stvarnom vremenu tijekom učenja (Raja, Nagasubramani, 2018; Boronahin, 2018). Osim na uporabu suvremene tehnologije i sposobnost integriranja u poučavanje, istraživanja ukazuju na znanja i vještine primjene suvremenih nastavnih strategija te vrednovanje svih dimenzija nastavnoga rada (Peko, Mlinarević, 2012). Takvo poboljšavanje i unaprjeđivanje nastave i obrazovanja, usklađeno sa suvremenim znanstvenim spoznajama, zahtijeva didaktičko-metodički visoko kompetentne stručnjake koji su osposobljeni za kreativno i kvalitetno planiranje i pripremanje te realiziranje nastavnog sadržaja (Curtis, 2012; Brust Nemet, Sili, 2016; Treffinger 
et al., 2002). Izrazito su važne - osim općih kompetencija iz područja rada, disciplinarno ili interdisciplinarno orijentiranih, te stručno-metodičke osposobljenosti - i one specifične kompetencije koje se odnose na procese spoznavanja u nastavi, pristupe u učenju, a reflektiraju se na primjenu suvremenih nastavnih aktivnosti, metoda i metodičkih oblika rada te oblika i načina praćenja i vrednovanja (Buljubašić-Kuzmanović, 2003). Iz literature je vidljivo kako su suvremene tendencije u nastavi usmjerene na reduciranje svih didaktičkih elemenata tradicionalnog poučavanja (Bognar, Matijević, 2002; Borić, 2013). S aspekta nastavnih strategija ističe se napuštanje usmjerenosti na sadržaj i nastavnika te uspostavljanje otvorene interakcije između studenta i nastavnika uz promicanje aktivnog učenja, kritičkog i stvaralačkog mišljenja te rješavanja problema i istraživački orijentiranog poučavanja (Vizek Vidović et al., 2003; Nikčević-Milković, 2004; Woodlief, 2007; Škojo, 2016). Izbor će nastavnih strategija, iako dominantno ovise o nastavnom području, svakako ovisiti o ishodu nastavnog sata, vrsti i složenosti sadržaja, razvojnom stupnju mišljenja studenta te o dostupnosti nastavnih medija. Osim navedenog, nastavne se strategije, s ciljem najpovoljnijeg ishoda učenja, odabiru s obzirom na obrazovne preferencije studenata, interese, iskustva i motivaciju za pojedini kolegij (Yager, 1991).

Nastavne metode, kao važan dio nastavnih strategija, čine veliki utjecaj na prijenos sadržaja na učenike. Budući da nijedna metoda ne može samostalno osigurati realizaciju svih ishoda učenja, cilj je nastavnika ostvariti metodički raznoliku nastavu. Uz već poznate i priznate verbalne metode, vizualne, auditivne i prakseološke metode (Mužić, 1999), ali i projektno učenje te učenje zasnovano na načelima postavljanja i rješavanja problema (problem-based learning, PBL), za ostvarivanje dinamične i metodički kreativnije nastave koriste se i nastavne metode ERR sustava (Jensen et al., 2001). Budući da se velik broj suvremenih metoda ostvaruje u grupnoj dinamici kao suradničko učenje, razvidno je prebacivanje težišta $\mathrm{s}$ frontalne nastave na nastavu koja će kombinirati i grupni oblik i rad u paru uz neizostavni individualni (individualizirani) oblik (Beard, Mc Pherson, 2019). Kao i u navedenim didaktičkim komponentama suvremene nastave, i u pogledu je vrednovanja, praćenja i ocjenjivanja studenata primarno razvidna promjena pristupa. Dok je u tradicionalnoj nastavi vrednovanje služilo isključivo za utvrđivanje razine uspjeha studenta u odnosu na prethodno propi- 
sanu normu (Buljubašić-Kuzmanović, 2002), suvremena se evaluacija odnosi na brojne aktivnosti kojima se sustavno prati napredovanje studenata (Knight, 1995). Nizom postupaka utvrđuje se kakvoća i količina usvojenog sadržaja i naglasak se stavlja na formativno izvještavanje o napredovanju tijekom poučavanja, kao i na povezanost između metoda poučavanja, metoda vrednovanja, kriterija vrednovanja i ishoda učenja. Upravo je istaknuta povezanost među navedenim elementima važan dio u jasnoći i transparentnosti cijelog procesa vrednovanja postignuća studenata.

Pri analizi visokoškolske umjetničke nastave potrebno je imati u vidu da je pristup nastavi izrazito personaliziran i usmjeren na realizaciju osobnog umjetničkog potencijala studenta (Jerković, 2019). Studenti na umjetničkim studijima identificirani su kao umjetnički predisponirani pojedinci te se kao takvi upisuju na visokoškolske studijske programe. Tijekom studija, a osobito u prvim godinama studiranja, nastava je usmjerena na razvijanje spektra umjetničkih tehnika i vještina s ciljem izgradnje studentova vlastitoga umjetničkog izraza. Nastavu karakterizira individualiziran mentorski pristup radu i suradnički odnos studenta i nastavnika koji je i sam istaknuti umjetnik iz istog područja. Svojim umjetničkim radom, nastavnik-umjetnik djeluje i kao model u izravnoj primjeni metode rada po modelu, stoga je česta početna identifikacija studenata umjetnosti s umjetničkim radom nastavnika (Cvejić, Cvejić, 2009). U umjetničkoj nastavi koriste se različite nastavne metode karakteristične za određeno umjetničko područje, a koje su povezane sa zakonitostima struke, ali i s teorijama učenja i kognitivnih stilova (Clark, 2008). Zbog homogenosti i veličine studijskih grupa (klasa), pri čemu su grupe na umjetničkim studijima u pravilu uvijek manje brojne od ostalih, moguća je dominacija jednog od stilova s obzirom na područje umjetnosti koje se poučava. Tako je moguće da su studenti likovne umjetnosti dominantno vizualni, a studenti glazbe dominantno auditivni tipovi. Na nastavnicima je da uravnoteženom i fleksibilnom primjenom raznolikih aktivnosti zadovolje stilove učenja svih studenata (Borić, 2013). Umjetničkim-nastavnim metodama kao što su učenje po modelu, metoda Stanislavski, metoda Grotowski, metoda djelovanja, metoda fizičkih radnji, metoda introspekcije, metoda vođenja dnevnika, Vennardove metode učenja glazbe, mehanistička, intuitivna i figurativna metoda te druge (Gospić Županović, 2016; Jerković, 2019; 
Raponja, 2018; Stjepanović, 2013; Vennard, 1967) zajedničko je da su procesno orijentirane, podrazumijevaju snažnu prisutnost nastavnika u svojstvu moderatora procesa, permanentnu introspekciju i refleksivnost studenta te konstantnu dvosmjernu evaluaciju svih segmenata studentskoga rada.

Otvorenost prema iskazanim promjenama, ali i stalno promišljanje i jačanje nastavničkih kompetencija osnovni je preduvjet za uspješno djelovanje u obrazovanju koje ima stalne mijene. Nastavnik stalno podliježe kritičkom osvrtu i analizi vlastita rada (Hercigonja, 2018). Upravo je kritičko promišljanje o metodičkim postupcima u nastavi i pronalaženje načina za unaprjeđenje prakse kroz redovito praćenje recentne literature, kao i drugih oblika organiziranih programa cjeloživotnog učenja, osnovna pretpostavka za napredak i razvoj (Jurčić, 2014). Promišljanje o vlastitoj učinkovitosti i usklađenosti sa zahtjevima suvremenog društva neupitne su kategorije nastavničkog poziva što je razvidno iz brojnih istraživanja (Ball, Forzani, 2009; Burn et al., 2003; Conway, Clark, 2003) u kojima se naglašava da je nastavnikova fleksibilnost u strukturiranju nastave i otvorenost prema novim nastavnim idejama, kao i permanentni rad na vlastitim kompetencijama, pravi put prema suvremenom oblikovanju nastave.

\section{Metoda}

\section{Cilj}

Cilj provedenog istraživanja bio je analizirati i utvrditi obilježja nastave, odnosno primjene nastavnih metoda i postupaka, oblika rada na nastavi, kao i postupke vrednovanja i ocjenjivanja studentskih postignuća na jednom većinski umjetničkom visokom učilištu u sastavu javnog sveučilišta s područja Republike Hrvatske. Kako bi se istražilo postoje li različitosti u primijeni nastavnih strategija u visokoškolskoj nastavi s obzirom na karakteristike područja studijskog programa (umjetnost vs. znanost), identificirane su i istražene i osnovne razlike $\mathrm{u}$ nastavnom radu s obzirom na područje i polje izbora u akademsko zvanje nastavnika. 


\section{Sudionici}

Istraživanje je provedeno na prigodnom uzorku od 93 nastavnika što čini 78,81 \% od ukupnog broja nastavnika visokog učilišta. Ovaj uzorak činilo je 55,9 \% ženskih i 44,1 \% muških sudionika u dobi od 25 do 63 godina $(\mathrm{M}=42,86, \mathrm{SD}=9,638) \mathrm{s}$ prosječnim radnim stažem ispitanika od 16 godina $(\mathrm{M}=15,99, \mathrm{SD}=9,613)$ od kojih je 54,8 \% (51) izabrano u umjetničko-nastavno, nastavno ili suradničko zvanje u umjetničkom području, 36,6 \% (34) u znanstveno područje (društvenih i humanističkih znanosti) te $8,6 \%$ (8) u interdisciplinarno znanstveno područje.

Tablica 1. Opis uzorka $(\mathrm{N}=93)$

\begin{tabular}{|l|l|c|c|}
\cline { 3 - 4 } \multicolumn{2}{|l}{} & N & $\%$ \\
\hline \multirow{4}{*}{ Spol } & Muško & 41 & 44,1 \\
\cline { 2 - 4 } & Žensko & 52 & 55,9 \\
\hline \multirow{5}{*}{ Polja } & Umjetnosti & 51 & 54,8 \\
\cline { 2 - 4 } & Znanosti & 34 & 36,6 \\
\cline { 2 - 4 } & Interdisciplinarno znanost i umjetnost & 8 & 8,6 \\
\cline { 2 - 4 } & $\begin{array}{l}\text { Odsjek za vizualne i medijske } \\
\text { umjetnosti }\end{array}$ & 15 & 16,1 \\
\hline \multirow{5yy}{*}{} & Glazbena umjetnost & 28 & 30,1 \\
\cline { 2 - 4 } & Kazališna umjetnost & 17 & 18,3 \\
\cline { 2 - 4 } & Primijenjena umjetnost & 14,0 \\
\cline { 2 - 4 } & $\begin{array}{l}\text { Kulturološki studiji u području } \\
\text { društvenih i humanističkih znanosti }\end{array}$ & 20 & 21,5 \\
\cline { 2 - 4 } & Likovna umjetnost & 15 & 16,1 \\
\hline
\end{tabular}

\section{Mjerni instrumenti}

Za potrebe istraživanja konstruiran je upitnik koji se u prvom dijelu sastojao od pitanja koja se odnose na sociodemografska obilježja ispitanika (spol, dob, godine nastavnog staža, područje i polja izbora u 
zvanje). Drugi je dio obuhvaćao pitanja višestrukog odabira svrstana u dvije kategorije. Prvi se set pitanja odnosio na primjenu nastavnih metoda i postupaka te oblika rada na nastavi.

Od nastavnika se tražilo da na skali Likertovog tipa (od 1 - uopće nisu prisutne, do 5 - prisutne su na svakom satu) procijene učestalost korištenja 17 aktivnosti u nastavi kolegija koje predaju. Primjer aktivnosti koje su nastavnici procjenjivali: aktivno sudjelovanje studenata na nastavi, izlaganje seminarskih radova, pisani ispit i slično. Nadalje, ispitane su metode izvođenja nastave. Od nastavnika se tražilo da od 20 ponuđenih metoda (usmeno izlaganje, pripovijedanje, razgovor itd.) odaberu sve one koje koriste u svojoj nastavi. Ispitani su i parametri za odabir nastavnih metoda, pri čemu su nastavnici mogli između osam ponuđenih odabrati sve one koje koriste $u$ radu. Također je ispitana $i$ učestalost primjene novih metoda rada i procjenjivanja u poučavanju (na skali Likertovog tipa od 1 - ne, nikada, do 5 - da, vrlo često). Jednim pitanjem ispitano je promišljanje nastavnika pri odabiru nastavnih metoda o aktivnom sudjelovanju studenata u nastavi (na skali Likertovog tipa od 1 - ne, nikada, do 5 - da, vrlo često). Sudionike se pitalo o utjecaju odabira metoda rada u nastavi na ishode učenja kod studenata i utjecaju odabira metoda rada u nastavi na zanimljivost nastave (ukupno dva pitanja na skali Likertovog tipa od 1 - ne, ne utječe, do 4 - da, u potpunosti). Ispitano je koje oblike nastave nastavnici koriste. Od ponuđenih pet oblika nastave (frontalna nastava, grupni rad, rad u paru itd.) mogli su odabrati sve one koje koriste.

Drugi set pitanja bio je usmjeren na evaluaciju rada studenata. Ispitani su načini praćenja rada studenata u nastavi, pri čemu su nastavnici od 12 ponuđenih načina mogli odabrati sve one koje koriste (primjeri načina praćenja: pohađanje nastave, aktivnost na nastavi, seminarski rad itd.). Oblici provjere rada studenata ispitani su jednim pitanjem u kojemu su nastavnici mogli od četiri ponuđena odgovora odabrati sve koji se odnose na njih (praktični oblik provjere rada studenata - izvedba, kreacija i izlaganje umjetničkog djela ili rada, usmeni oblik - razgovor, diskusija/rasprava, izlaganje, elaboracija umjetničkog rada itd.). Također su ispitane i metode procjene studentskog rada. Nastavnici su mogli od ponuđenih odabrati sve metode procjene koje koriste (procjenjivanje praktičnog rada, rada na projektu itd.), ali i navesti neke koje nisu ovdje navedene. 
Nakon anketiranja i prikupljanja provedena je statistička obrada podataka te su prikazani rezultati za sve mjerene varijable.

\section{Postupak}

Popunjavanje upitnika provedeno je na internetu u obliku Google dokumenta. Istraživanje je provedeno u siječnju i veljači 2020. godine. Nastavnike se zamolilo da izdvoje 15 minuta za popunjavanje online upitnika. Istraživanje je bilo dobrovoljno i anonimno.

\section{Rezultati i interpretacija}

Visoko učilište na kojemu je provedeno istraživanje je multidisciplinarna, primarno umjetnička institucija na kojoj se izvode preddiplomski i diplomski sveučilišni studijski programi u umjetničkom području (28), poljima: glazbene (9), kazališne (9), likovne (3) i primijenjene (7) umjetnosti te u području društvenih (4) i humanističkih znanosti (1), poljima: ekonomije, informacijskih i komunikacijskih znanosti i filologije (5). Ta se institucija stoga pokazala kao dobro mjesto za istraživanje razlika između nastavnoga rada u različitim područjima i poljima znanosti i umjetnosti. Sukladno široko postavljenim studijskim programima, nastavnici visokog učilišta stječu umjetničko-nastavna, znanstveno-nastavna, nastavna i suradnička zvanja iz svih navedenih područja i polja te izvode kolegije koji se sadržajno, procesno, koncepcijski i organizacijski znatno razlikuju. Uvidom u studijske programe utvrđeno je da nastavnici izvode kolegije koji se mogu razvrstati u četiri osnovne kategorije: umjetnički kolegiji, teorijski kolegiji, kolegiji koji podjednako objedinjuju teoriju i praksu te praktični stručni kolegiji. Udio prikupljenih odgovora okvirno odgovara i udjelu kolegija koji se mogu razvrstati prema navedenim kategorijama kolegija, a koji se nalaze u studijskim programima.

Prije početka statističke obrade provjerena je normalnost distribucija za aktivnosti koje nastavnici koriste u nastavi. Provjerom indeksa simetričnosti i spljoštenosti pokazalo se da su apsolutne vrijednosti indeksa simetričnosti manje od tri, a indeksa spljoštenosti manje od deset. Prema tome distribucije se mogu smatrati normalnima (Kline, 2005) 
te su zadovoljeni preduvjeti za korištenje parametrijskih postupaka u daljnjoj obradi rezultata.

\section{Procjena nastavnika o nastavnim postupcima, aktivnostima, metodama i oblicima rada u visokoškolskoj nastavi}

Analizom rezultata o učestalosti korištenja pojedinih aktivnosti u nastavi može se zaključiti da nastavnici u svojoj nastavi koriste široki spektar aktivnosti. Odabrane aktivnosti odgovaraju aktivnostima navedenim u studijskim programima visokog učilišta i prirodi kolegija.

Iz prikaza (Tablica 2) razvidno je da polovina nastavnika najčešće koristi grupno prezentiranje, kao i samostalni način predstavljanja nastavnoga sadržaja (50,6 \% na svakom satu i 24,7 \% često, Mode=5). Više od polovine nastavnika u odgovorima iskazuje kako koristi praktični rad (51,6 \% na svakom satu i 19,3\% često, Mode=5). Aktivnosti koje nastavnici u najmanjoj mjeri koriste jesu portfolio, koji ukupno $58,1 \%$ nastavnika uopće ne koristi (Mode=1), i dnevnik, koji ukupno $55,9 \%$ nastavnika uopće ne koristi (Mode=1). Više od $40 \%$ nastavnika uopće ne koristi pisani ispit (Mode=1), kao niti esej na zadanu temu $($ Mode $=1)$ te projekt (Mode=1) koji ne koristi više od $30 \%$ nastavnika. Veliku pozornost nastavnici pridaju aktivnom sudjelovanju studenata u nastavnim aktivnostima te polovina nastavnika $(51,6 \%)$ na svakom satu sustavno prati i bilježi aktivnost. Sukladno s tim, gotovo polovina nastavnika na svakom je satu usmjerena prema aktivnostima kontinuirane provjere znanja $(48,4 \%)$. 


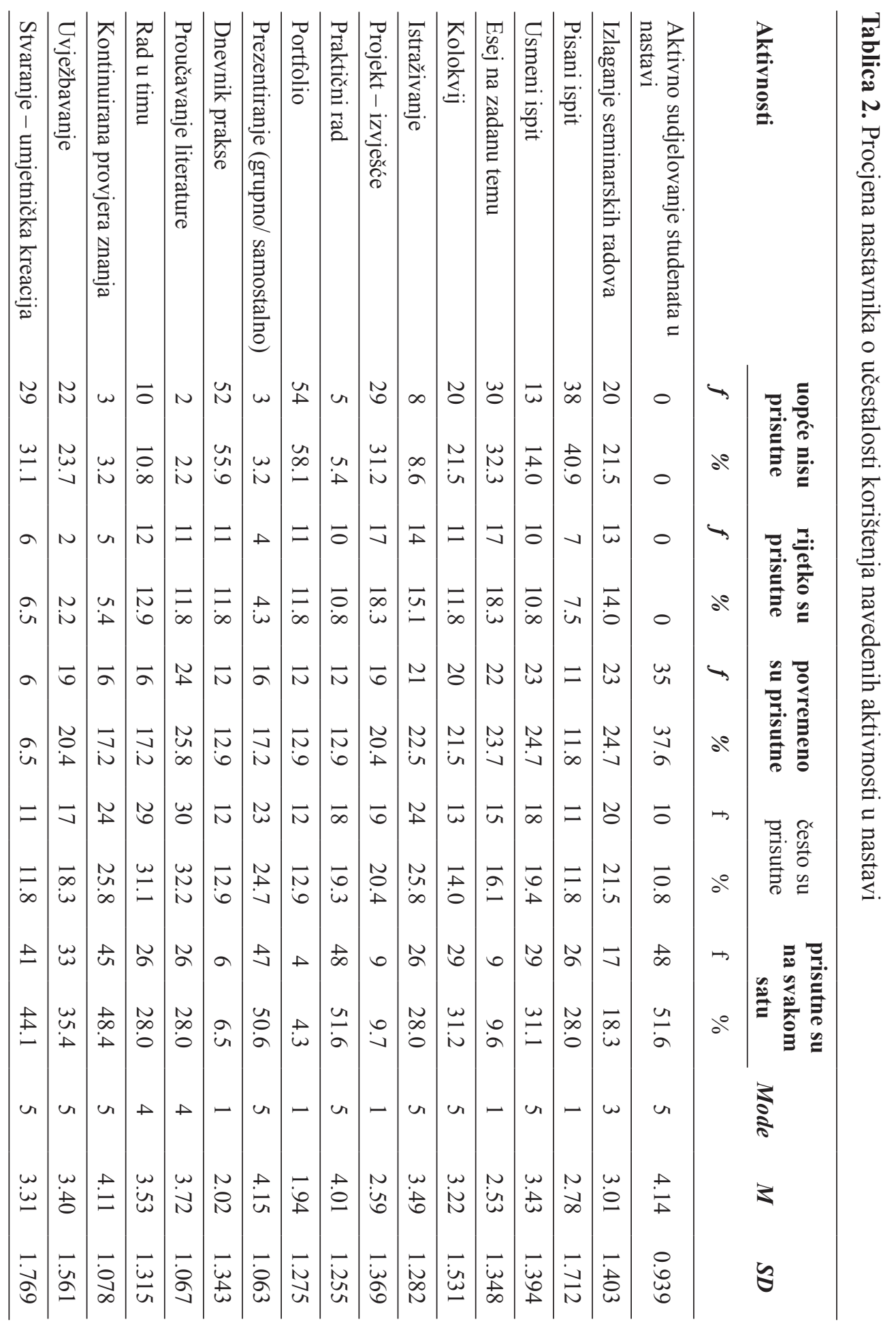




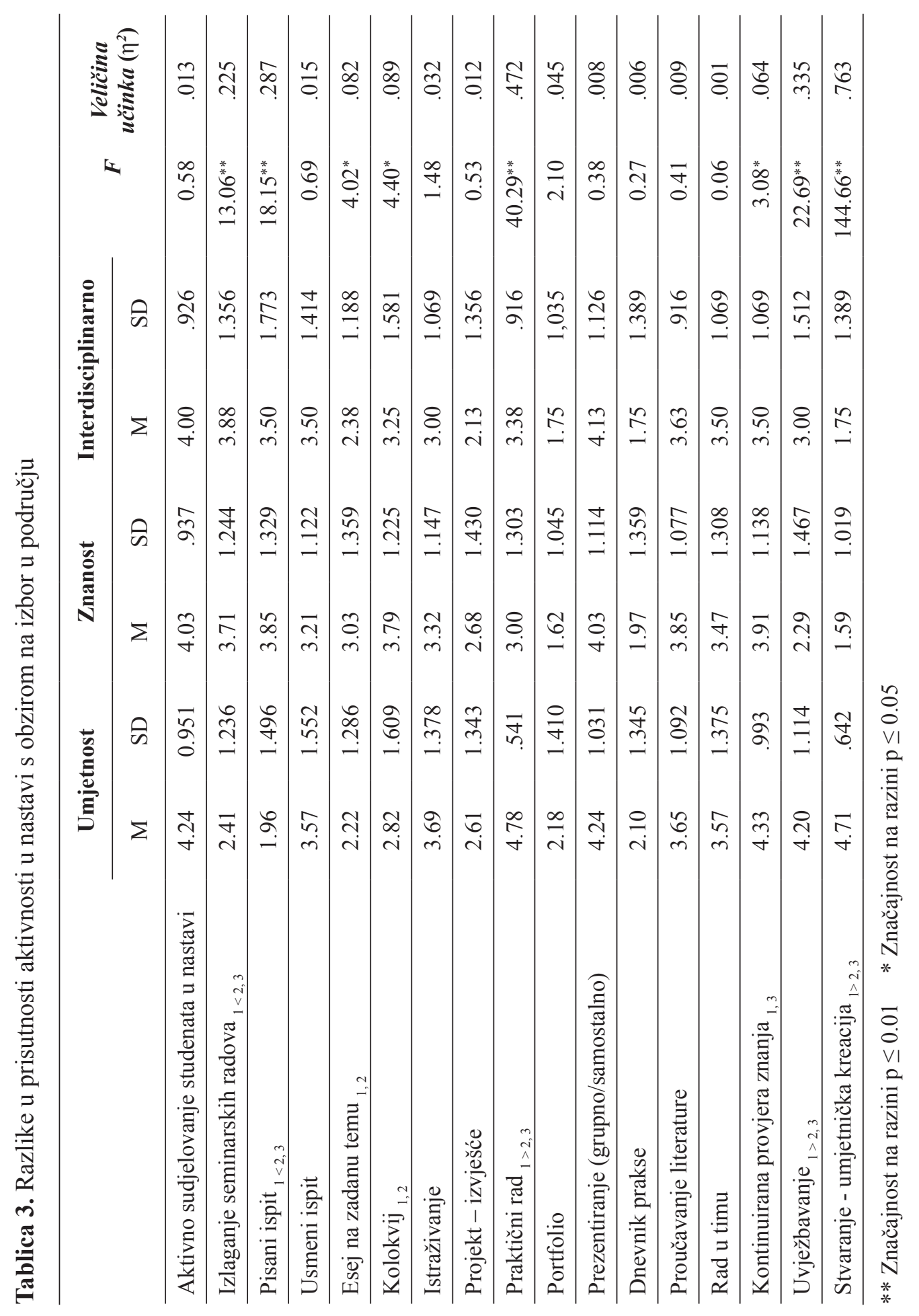


Multivarijatnom analizom varijance ispitane su razlike u prisutnosti različitih aktivnosti u nastavi s obzirom na izbor u području nastavnika (Tablica 3). Dobivena je statistički značajna razlika u izlaganju seminarskih radova $\left(\mathrm{F}=13,056, \mathrm{p}<, 001\right.$, partial $\eta^{2=0,225)}$ i pisanih ispita $\left(\mathrm{F}=18,149, \mathrm{p}<, 001\right.$, partial $\left.\eta^{2=0} 0,287\right)$, pri čemu nastavnici koji imaju izbor iz umjetnosti značajno manje od nastavnika koji imaju izbor u znanosti i onih koji imaju interdisciplinarni izbor koriste aktivnost koja se odnosi na izlaganje seminarskih radova i pisane provjere znanja. Također je dobivena značajna razlika u učestalosti aktivnosti eseja na zadanu temu $\left(\mathrm{F}=4,020, \mathrm{p}<, 005\right.$, partial $\left.\eta^{2}=0,082\right)$ i kolokvija $(\mathrm{F}=4,404$, $\mathrm{p}<, 005$, partial $\eta^{2=0,089}$ ), pri čemu nastavnici koji imaju izbor u znanstvenom području značajno češće koriste ove dvije aktivnosti u nastavi od nastavnika koji imaju izbor u umjetničkom području.

Također se pokazala, očekivano, značajna razlika u korištenju slje-

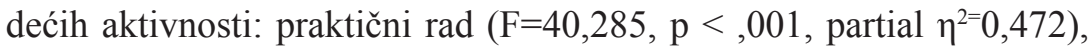
uvježbavanje $\left(\mathrm{F}=22,691, \mathrm{p}<, 001\right.$, partial $\eta^{2=0,335)}$ i stvaranje - umjet-

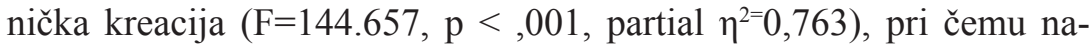
stavnici koji imaju izbor iz umjetnosti značajno više od nastavnika koji imaju izbor u znanosti i onih koji imaju interdisciplinarni izbor koriste aktivnosti praktičnoga rada, uvježbavanja i stvaranja - umjetničke kreacije. Značajna je razlika potvrđena i u aktivnosti kontinuirane provjere

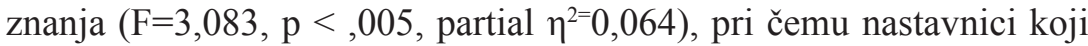
imaju izbor iz umjetnosti značajno više koriste kontinuirane provjere znanja od nastavnika koji imaju izbor u znanstvenom ili interdisciplinarnom području. Može se zaključiti da nastavnici izabrani u području znanosti češće biraju za visoko obrazovanje terminološki i organizacijski tradicionalnije aktivnosti kao što su izlaganje seminarskih radova, pismene provjere znanja, pisanje eseja na zadanu temu i kolokvij, dok nastavnici izabrani u umjetničkom području češće koriste u visokom obrazovanju slabije zastupljene terminološki i sadržajno nedovoljno prepoznatljive i afirmirane nastavne aktivnosti kao što su stvaranje umjetnička kreacija, uvježbavanje i praktični rad. To ni u kojem slučaju ne znači da su te aktivnosti manje vrijedne u odnosu na ranije spomenute tradicionalne aktivnosti, nego znači da se one u sustav visokog obrazovanja u smislu normiranja i vrednovanja nisu dovoljno uvriježile s obzirom na prisutnost određene sadržajne nekoherentnosti koja proizlazi iz specifičnosti sadržaja umjetničke nastave. Budući da je umjetnička 
nastava u znatno manjem postotku prisutna u sustavu visokog obrazovanja, ne iznenađuje činjenica da je prevaga znanstvene paradigme, karakteristična za cijeli sustav, prisutna i u slučaju imenovanja nastavnih aktivnosti. Tako se u umjetničkoj nastavi također koriste nazivi kao što su predavanja, seminari, izlaganja i slično, iako je riječ o potpuno različitim konceptima i procesima.

Multivarijatnom analizom varijance ispitane su razlike u prisutnosti različitih aktivnosti u nastavi s obzirom na polja umjetnosti te je potvrđena razlika koja se odnosi na kontinuiranu provjeru znanja. Ovakav oblik provjere znanja značajno više koriste nastavnici koji rade $\mathrm{u}$ polju glazbene, kazališne i primijenjene umjetnosti od nastavnika koji rade u polju kulturoloških studija, nastavnika iz područja društvenih i humanističkih znanosti $\left(\mathrm{F}=4,462, \mathrm{p}<, 001\right.$, partial $\left.\eta^{2=0} 0,169\right)$. Na temelju dobivenih rezultata može se zaključiti da su kontinuirana provjera znanja i praćenje napretka studenta više karakteristični za područje reprodukcijskih i izvedbenih umjetnosti u kojemu student napreduje zahvaljujući intenzivnom mentorskom vođenju i kontinuiranoj suradnji s nastavnikom koja za svrhu ima višestruku razmjenu povratnih informacija o napretku studenta, a što je jedna od karakteristika umjetničkih istraživanja. Dok se studenti u društvenim i humanističkim znanostima za ispite najčešće pripremaju samostalno i individualno, dinamika pripreme studenata umjetničkih studija (glazbene, kazališne i primijenjene umjetnosti) često uključuje suradnju s drugim studentima iz klase. Kako bi moderirali nastavni rad, napredak i umjetničku realizaciju svih studenata u skupini, nastavnici koji djeluju u navedenim poljima umjetnosti češće od ostalih kontinuirano vrednuju studentska postignuća i na taj način utječu na poboljšanje uvjeta za ostvarenje skupnih ishoda učenja kolegija. Nastava se na umjetničkim studijima također često izvodi u relativno malim grupama (od jednog studenta do maksimalno deset studenata) tako da je nastavnicima znatno lakše kontinuirano pratiti i usmjeravati individualni napredak svakog studenta. 


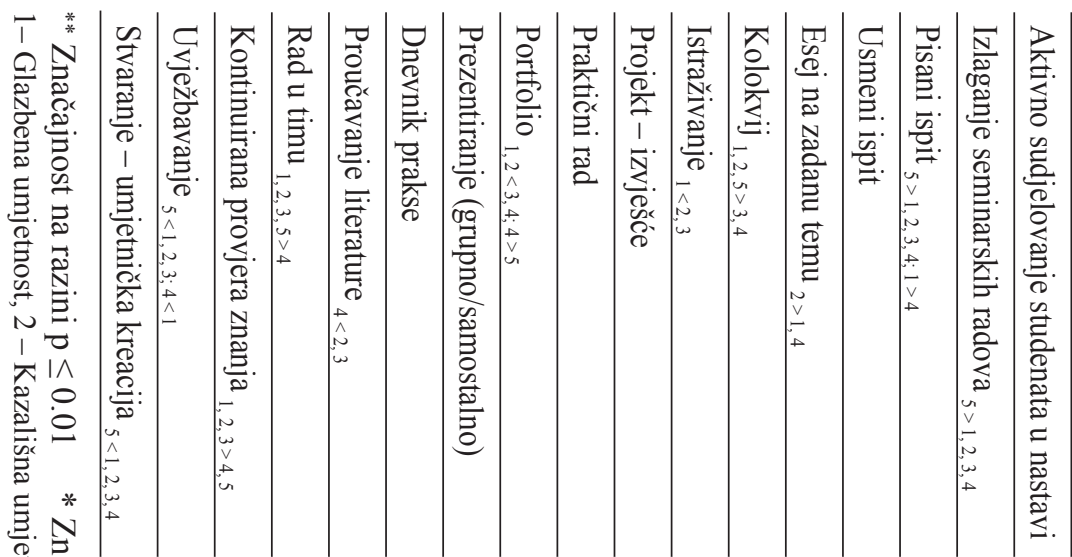

है

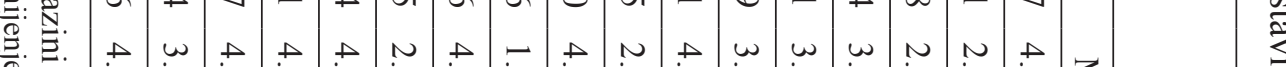

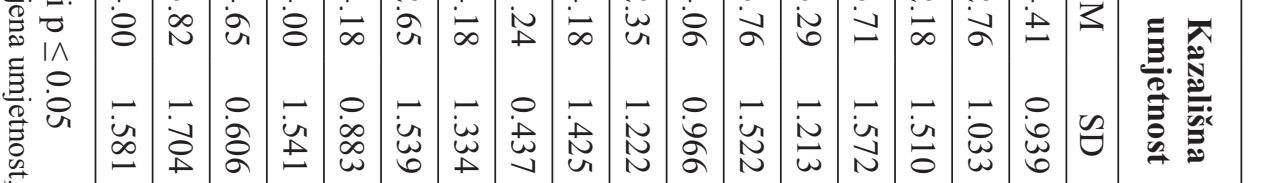

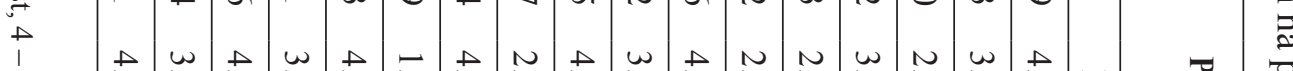

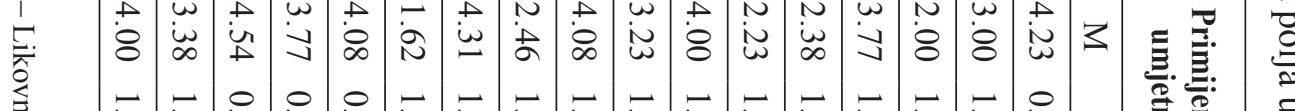

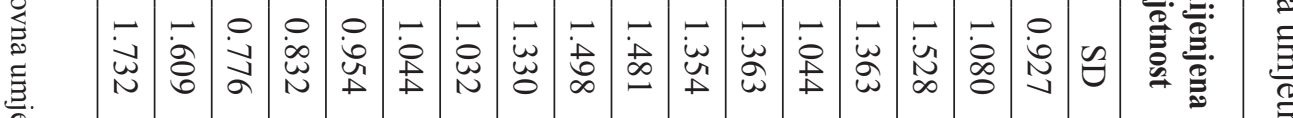

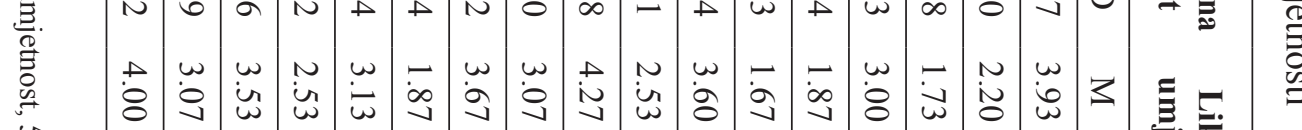

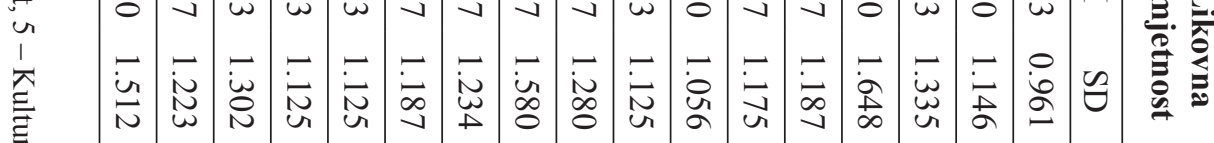

要

$\overline{8}$

胥

歨

的

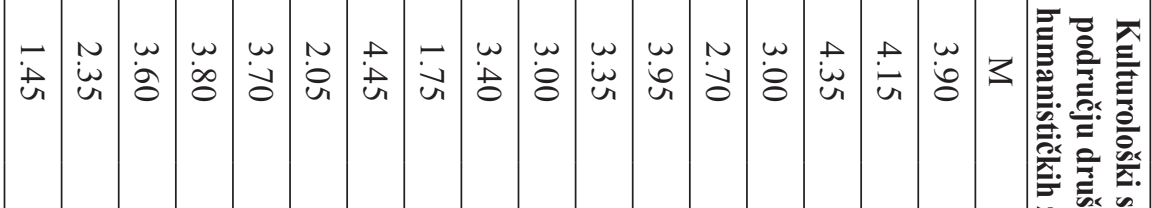

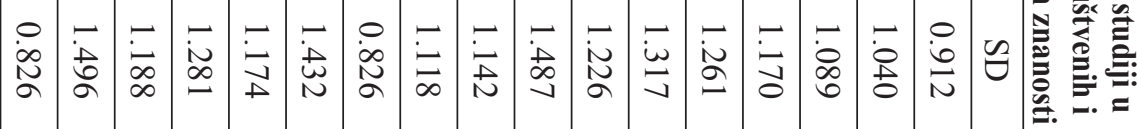

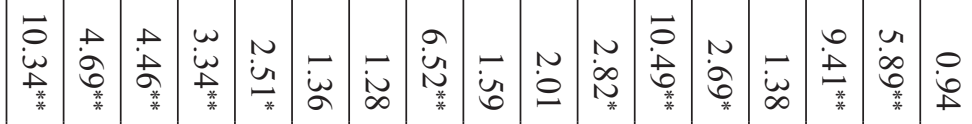

辰 
Multivarijatnom analizom varijance ispitane su razlike u prisutnosti različitih aktivnosti u nastavi s obzirom na polja umjetnosti (Tablica 4). Dobivena je statistički značajna razlika u izlaganju seminarskih radova $\left(\mathrm{F}=5,899, \mathrm{p}<, 001\right.$, partial $\left.\eta^{2}=0,211\right)$, pri čemu nastavnici koji rade u polju glazbene umjetnosti značajno više koriste aktivnosti koje se odnose na izlaganje seminarskih radova od nastavnika koji rade u ostalim poljima. Značajna se razlika pokazala i u učestalosti korištenja pisanih

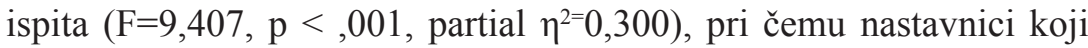
rade u polju kulturoloških studija u području društvenih i humanističkih znanosti značajno više koriste pisane ispite od svih ostalih nastavnika, a nastavnici koji rade u polju glazbene umjetnosti značajno više koriste pisane ispite od nastavnika koji rade u polju likovne umjetnosti. Esej na zadanu temu značajno više koriste nastavnici koji rade u polju kazališne umjetnosti od nastavnika koji rade u polju glazbene i likovne umjetnosti $\left(F=2,690, p<, 005\right.$, partial $\left.\eta^{2=0}, 109\right)$. Kolokvij značajno više koriste nastavnici koji rade u polju glazbene, kazališne umjetnosti i kulturoloških studija u području društvenih i humanističkih znanosti od nastavnika koji rade u polju primijenjene i likovne umjetnosti $(\mathrm{F}=10.485, \mathrm{p}<$ .001 , partial $\eta^{2}=0.323$ ).

Istraživanje značajno više koriste nastavnici koji rade u polju kazališne i primijenjene umjetnosti od nastavnika koji rade u polju glazbene

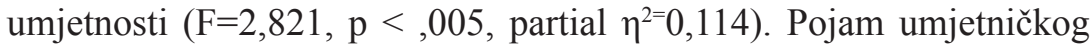
istraživanja ne može se jednoznačno promatrati u različitim umjetničkim poljima. Budući da pojam 'istraživanje' implicira traganje za originalnim uvidom, u različitim umjetnostima istraživanje se mora promatrati u kontekstu umjetnika kao istraživača i medija realizacije. Suoranta et al. (2014) navode da umjetničko istraživanje podrazumijeva umjetnički proces (djelovanje unutar određene umjetničke prakse) uz dodatak zauzimanja kontekstualnog, interpretativnog, konceptualnog i narativnog stajališta. Može se zaključiti da istraživanje kao aktivnost nastave u području kazališne i primijenjene umjetnosti djelomično slijedi Feyerabendovu postmodernističku ideju (2010) umjetničkog istraživanja utjelovljenu u metaforičkoj sintagmi anything goes, a koja implicira da na početku bilo kojeg postupka ne smije biti ograničenja te da istraživački proces treba ostati otvoren i potencijalan, da istraživanje ne treba započeti s jasno razjašnjenim i navedenim problemom, već igranjem, eksperimentiranjem i isprobavanjem stvari (Feyerabend, 2010, 
157). Nastavnici koji rade sa studentima preddiplomskih umjetničkih studija u prvom su redu usmjereni na ovladavanje umjetničkim procesima određene umjetničke prakse koju nadograđuju izgradnjom kritičkog mišljenja i individualnog gledišta u kasnijim fazama obrazovanja. Istraživanje kao nastavna aktivnost donosi u kurikulum umjetničkih studija nužnu razinu »otvorenosti i potencijalnosti« (Feyerabend, 2010) koja je preduvjet za realizaciju kreativnih i inovativnih oblika umjetničkog djelovanja. Iako je prema ovom istraživanju utvrđeno da istraživanje kao nastavnu aktivnost češće koriste nastavnici u polju kazališne i primijenjene umjetnosti, to ne znači da se u drugim umjetnostima (prije svega u glazbenoj i likovnoj) istraživački rad ne koristi. To ponovno otvara pitanje terminološkog određenja postupaka i nastavnih aktivnosti u različitim umjetnostima, a koje je potrebno dodatno istražiti u budućnosti.

Iako je u suvremenoj didaktičkoj literaturi (Rolheiser et al., 2000; Stefani et al., 2007) razvidna široka primjena portfolia i naglašen pozitivan utjecaj na motivaciju u učenju i samorefleksiju, iz rezultata je razvidno kako portfolio dominantno koriste nastavnici koji rade u polju primijenjene i likovne umjetnosti $\left(\mathrm{F}=6,522, \mathrm{p}<, 001\right.$, partial $\eta^{2=0,229)}$, s naglaskom na to da ga nastavnici likovne umjetnosti tretiraju u osnovnom obliku, kao osobnu (radnu) mapu radova studenata.

Iz dobivenih rezultata koji se odnose na oblike nastavnoga rada razvidno je da najveći broj nastavnika koristi predavanja (96,8 \%), samostalne zadatke $(81,7 \%)$, seminare i radionice $(77,4 \%)$ te vježbe $(71 \%)$. U najmanjoj mjeri nastavnici koriste laboratorij (2,2\%) i obrazovanje na daljinu (14\%). ${ }^{1}$ Od aktivnosti koje nisu bile ponuđene, nastavnici su naveli da još koriste rad na projektima (dva nastavnika) te praktičan i konzultativan rad (po jedan nastavnik).

Ponovno se pokazalo da se nastavnici služe tradicionalnom nomenklaturom oblika nastavnoga rada u visokom obrazovanju, iako pod istim nazivljem podrazumijevaju različite oblike rada.

${ }^{1}$ Istraživanje je provedeno prije masovne primjene metode učenja na daljinu uslijed pandemije bolesti COVID-19. 


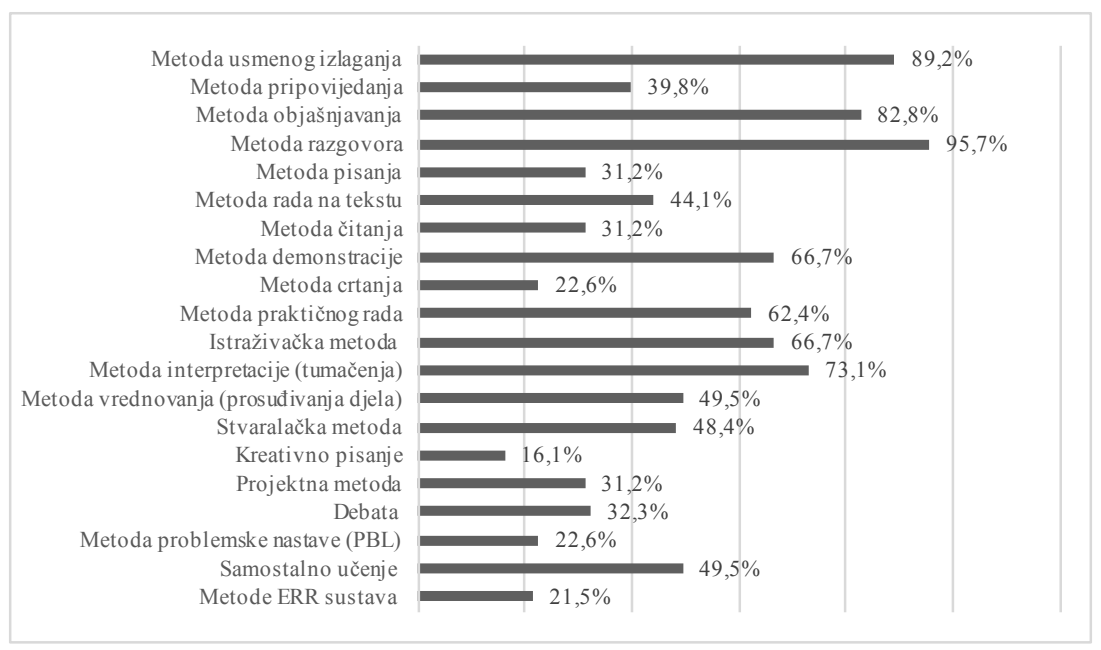

Slika 1. Metode koje nastavnici koriste u nastavi

Daljnje procjene nastavnika bile su usmjerene na ispitivanje metoda koje nastavnici koriste u nastavi (Slika 1). Na temelju iskaza nastavnika može se zaključiti da nastavnici u velikoj mjeri koriste različite metode u nastavi. Najviše ih koristi metodu razgovora $(95,7 \%)$, metodu usmenog izlaganja $(89,2 \%)$ i metodu objašnjavanja $(82,8 \%)$. U velikoj su mjeri zastupljene metode interpretacije (tumačenja) $(73,1$ $\%)$, metode demonstracije i istraživačka metoda $(66,7 \%)$ te metoda praktičnoga rada $(62,4 \%)$. Glede navedenih metoda, nastavnici su se izjasnili da u manjoj mjeri koriste metodu crtanja i metodu problemske nastave (22,6 \%), kao i metode ERR sustava (21,5\%), a u najmanjoj mjeri koriste kreativno pisanje (16,1\%).

Binarnom logističkom regresijskom analizom ispitan je doprinos demografskih varijabli metodama koje nastavnici koriste u nastavi. Od svih ispitivanih metoda koje nastavnici koriste u nastavi (20 ispitanih u istraživanju) značajnim su se pokazali modeli za zavisne varijable. Postotak koji objašnjavaju prediktorske varijable kreće se od više od $20 \%$ pa sve do nešto malo manje od $60 \%$. Značajnim prediktorima pokazale su se varijable 'izbor u području' i 'polja umjetnosti'. Iz rezultata je razvidno da nastavnici izabrani u znanstvenom području koriste metodu pisanja, metodu rada na tekstu, metodu čitanja i metodu problemske 
nastave više nego nastavnici izabrani u umjetničkom području. S druge strane, nastavnici izabrani u umjetničkom području koriste metodu demonstracije i stvaralačku metodu više nego nastavnici izabrani u znanstvenom području, a metodu praktičnog rada više od nastavnika izabranih u znanstvenom i onih izabranih u interdisciplinarnom području.

Izdvojena varijabla izbora u području i polju nastavnika očekivano sugerira češće korištenje onih nastavnih metoda koje su prikladnije za poučavanje sadržaja kolegija koji sveučilišni nastavnik kao istaknuti stručnjak u svom polju izvodi. U polju glazbene umjetnosti nastavnici se češće koriste metodom demonstracije nego nastavnici koji rade u polju primijenjene umjetnosti. Bitno je napomenuti da se metoda demonstracije koja, iako se može smatrati didaktički anakronom u glazbenoj umjetnosti, i dalje ima iznimno važnu ulogu. U glazbenom je kontekstu riječ o metodi po načelu sentire e imitare - slušanje i imitiranje, a koja je i danas dominantna metoda u poučavanju pjevanja ili instrumenta (Jerković, 2019).

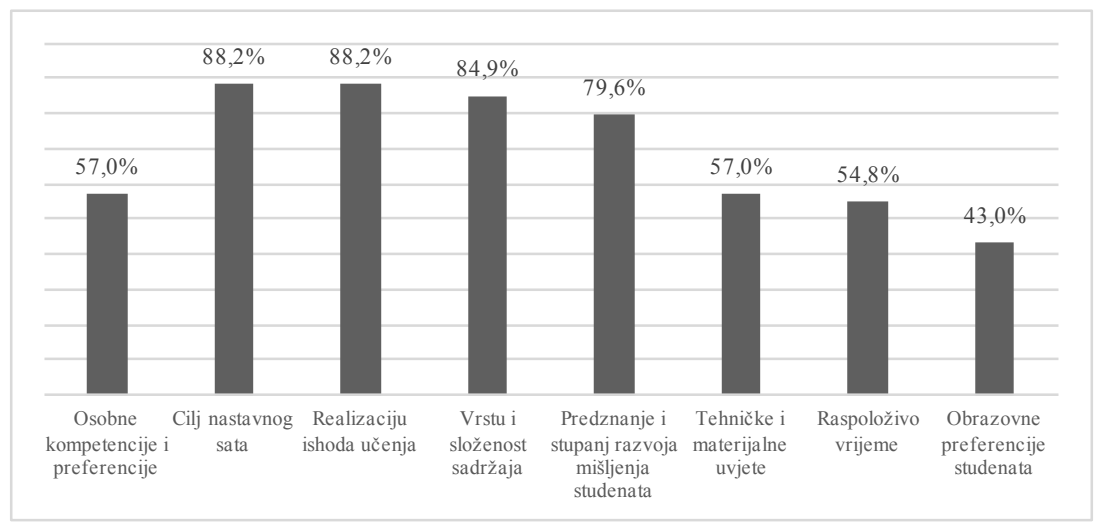

Slika 2. Parametri za odabir nastavnih metoda

Što se tiče parametara za odabir nastavnih metoda (Slika 2), nastavnici u obzir najviše uzimaju cilj nastavnoga sata i realizaciju ishoda učenja $(88,2 \%)$, zatim vrstu i složenost sadržaja $(84,9 \%)$ te predznanje i stupanj razvoja mišljenja studenata $(79,6$ \%). Više od polovine nastavnika u obzir uzima osobne kompetencije i preferencije, tehničke i materijalne uvjete te raspoloživo vrijeme, dok se najmanje u obzir uzimaju 
obrazovne preferencije studenata (spoznajni stil učenja) (43 \%). Iako je spoznajni stil, kao način na koji student spoznaje i obrađuje temu, iznimno bitan u nastavi (Hewitt, 2003), nastavnici su u odgovorima ukazali na to da im taj aspekt nije bitan u odabiru nastavnih metoda.

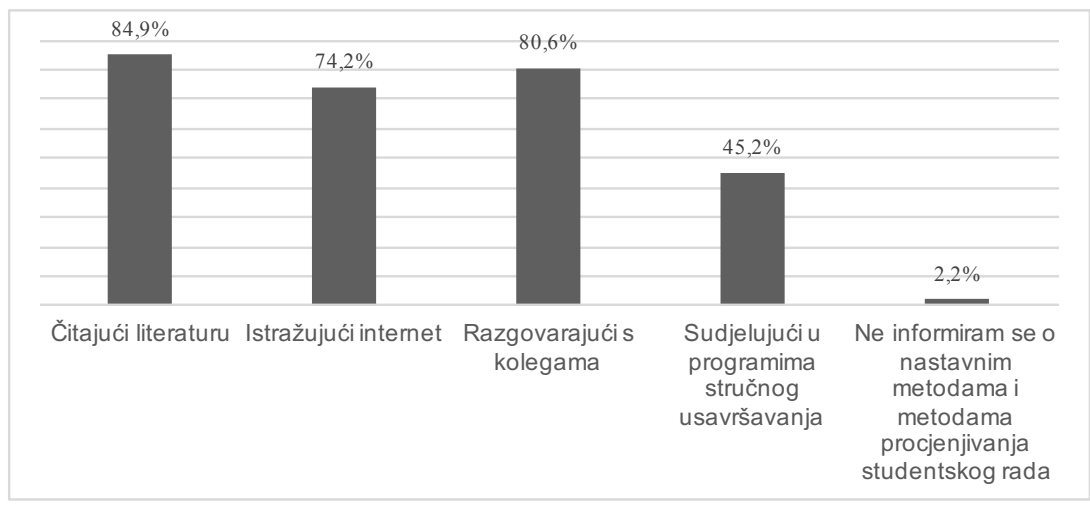

Slika 3. Načini stjecanja novih znanja o nastavnim metodama i metodama procjenjivanja rada studenata

U pogledu primjene novih metoda rada, nešto je više od 40 \% nastavnika navelo da vrlo često primjenjuje nove metode rada, a više od polovine to čini ponekad. Iz rezultata možemo zaključiti da gotovo svi ispitani nastavnici primjenjuju nove metode rada $(\mathrm{M}=4,37 ; \mathrm{SD}=0,567)$ te da su svjesni potrebe stalnog obogaćivanja svog znanja. Nova znanja nastavnici stječu čitajući literaturu (84,9\%), razgovarajući s kolegama $(80,6 \%)$ te istražujući sadržaje na internetu $(74,2 \%)$. Najmanji postotak nastavnika $(45,2 \%)$ nova znanja stječe sudjelujući u programima stručnog usavršavanja (Slika 3), što ukazuje na otvorene mogućnosti za osmišljavanje didaktičkih radionica, posebice na fakultetima na kojima se dominantno ne obrazuju budući nastavnici. Posebno ukazujemo na odgovore koje su nastavnici samostalno naveli, a odnose se na načine stjecanja novih znanja putem umjetničkog rada. Iz njihovih je odgovora ponovno uočljiva dualnost u primijenjenoj terminologiji između znanstvenog i umjetničkog područja. Nastavnici umjetničkog područja u odgovorima ističu da nove metode rada razvijaju putem samostalnog umjetničkog rada (istraživanja) te razgovorom s naprednim studentima, 
ali i gostujući na stranim sveučilištima te proučavajući njihove umjetničke radove.

Korištenje osobnog, introspektivnog odnosa nastavnika pri razvijanju novih nastavnih metoda rada može se ocijeniti vrlo kvalitetnim načinom razvijanja nastavnih metoda u području umjetnosti. Nastavnici koji djeluju kao aktivni umjetnici vlastitim umjetničkim radom djeluju i na unaprjeđenju svoga nastavnoga rada simulirajući pritom procese karakteristične za umjetnička istraživanja prema kojima se istraživanja provode unutar prakse, čineći djela koja su dio prakse (Suoranta et al., 2014). U ovom slučaju to znači da se unaprjeđenje nastavnih metoda $u$ umjetnosti odvija unutar procesa poučavanja, djelovanjem na realizaciji umjetničke prakse.

Iz odgovora nastavnika, prema kojima njih $88,2 \%$ navodi kako prilikom odabira nastavnih metoda vrlo često promišljaju o aktivnom sudjelovanju studenata u nastavi, a $11,8 \%$ to čini ponekad $(\mathrm{M}=4,88$; $\mathrm{SD}=0,325)$, razvidna je orijentiranost nastavnika prema suvremenoj nastavi u kojoj učenici aktivno sudjeluju u učenju, primjenjuju naučen sadržaj te suplaniraju i suorganiziraju tijek nastavnoga procesa.

U prilog didaktičkom usmjerenju nastavnika visokog učilišta prema suvremenom poučavanju idu i odgovori iz kojih je razvidno kako više od 60 \% nastavnika smatra da odabir metoda rada u nastavi ima izravan utjecaj na ostvarivanje ishoda učenja kod studenata, dok ih nešto manje od $40 \%$ smatra kako djelomično utječe $(\mathrm{M}=3,58 ; \mathrm{SD}=0,558)$. Također je važno istaknuti da $70 \%$ nastavnika procjenjuje da u potpunosti postoji utjecaj odabira metoda rada u nastavi na zanimljivost nastave, dok oko $30 \%$ nastavnika smatra da djelomično postoji takav utjecaj $(\mathrm{M}=3,70 ; \mathrm{SD}=0,461)$. Prilikom utvrđivanja broja nastavnih metoda koje nastavnici koriste u jednom nastavnom satu, najveći je broj nastavnika (57\%) naveo da koristi između 4 i 6 nastavnih metoda.

Nastavnici i prilikom procjene o oblicima nastave koje koriste $\mathrm{u}$ nastavi navode da u jednakoj mjeri koriste frontalnu nastavu i grupni rad $(80,6 \%)$, a zatim rad u paru (61,3\%). Individualnu nastavu kao oblik nastave provodi 51,6\% nastavnika, a individualizirani oblik nastave njih 46,2 \%. Iako su pojedini socijalni oblici imanentni određenom umjetničkom području, ipak je i kroz navedene rezultate razvidno usmjerenje prema suvremenoj nastavi koja se zasniva na pluralizmu u socijalnim oblicima koje nastavnici primjenjuju u poučavanju. Tomu u 
prilog možemo navesti i dopunjene odgovore koje su pojedini nastavnici na ovo pitanje istaknuli, a odnose se na kombinirani oblik i individualni oblik u skupnoj nastavi.

\section{Procjena nastavnika o načinu praćenja rada studenata u nastavi}

U odgovorima koji se odnose na praćenje rada studenata (Slika 4), više se od $90 \%$ nastavnika izjasnilo da rad studenata prati kroz aktivnost na nastavi $(97,8 \%)$ i pohađanje nastave $(92,5 \%)$. U velikoj mjeri to čine i putem praktičnoga rada $(75,3 \%)$, kontinuirane provjere znanja $(66,7 \%)$ i izlaganja seminarskih radova $(53,8 \%)$. Ponovno je i u ovom segmentu s obzirom na $25,8 \%$ nastavnika koji koriste usmene i pismene provjere razvidno da se umjetničko područje znatno razlikuje od znanstvenog. Nastavnici su još samostalno naveli da koriste ogledne vježbe i studentsko prezentiranje vlastitoga rada kao načine praćenja rada studenata, što su kategorije koje idu u prilog prethodnom zaključku o istaknutim razlikama među područjima.

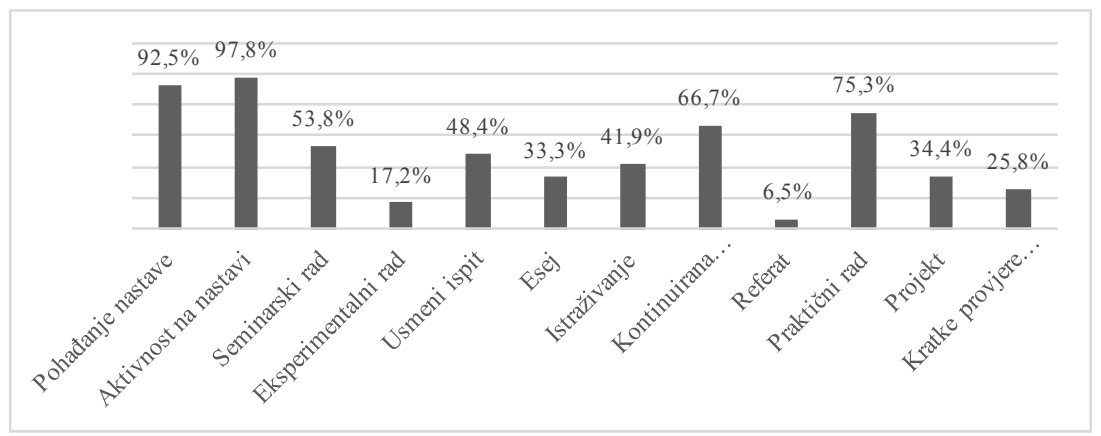

Slika 4. Načini praćenja rada studenata

U procjenama nastavnika o oblicima provjere studentskoga rada dobiveni rezultati ukazuju na to da nastavnici koriste sve navedene oblike provjere studentskoga rada: praktične (izvedba, kreacija i izlaganje umjetničkog rada ili djela), usmene (razgovor, diskusija/rasprava, izlaganje, elaboracija umjetničkog rada), pisane (test/kolokvij, završni ispit, seminarski rad, portfolio), kombinirane (usmeni i pisani oblik provjeravanja znanja). U najvećoj mjeri koriste usmene oblike provjere 
studentskoga rada kroz razgovor, diskusiju/raspravu, izlaganje, elaboraciju umjetničkog rada $(75,3 \%)$, a nešto manje od polovine nastavnika koristi kombinirane oblike, odnosno usmene i pisane oblike provjeravanja znanja (45,2 \%).

Nastavnici u najvećoj mjeri navode da koriste metode procjenjivanja kreativnih zadataka na određenu temu (74,2\%), procjenjivanje praktičnoga rada poput procjenjivanja uvježbanosti izvedbe, procjenjivanja provođenja zadataka u praksi i slično $(72 \%)$ te procjenjivanja specifičnih komunikacijskih i radnih vještina $(62,4 \%)$. S druge strane najmanje koriste metode procjene studentskog portfolija, odnosno procjenjivanje zbirke radova studenta $(23,7 \%)$ i procjenjivanje terenskog rada, poput procjenjivanja prikupljanih podataka i izvještaja (28\%). Nastavnici iz umjetničkog područja, osim ponuđenih odgovora, naveli se još neke metode procjene studentskoga rada koje koriste: proaktivnost na nastavi, iskazivanje kritičkog mišljenja, evaluacija napretka studenta te kombinirana metoda kreativnih zahtjeva.

Prije formuliranja zaključka potrebno je napomenuti nekoliko ograničenja provedenog istraživanja. Budući da je zamjetan nedostatak istraživanja visokoškolske umjetničke nastave, bilo kakva komparativna analiza u istraživanju nije bila moguća. Jedno od ograničenja ove studije je i izostanak analize i utvrđivanja razlika u obilježjima nastave s obzirom na tip zvanja nastavnog osoblja (suradnička, nastavna te znanstveno-nastavna zvanja). Također se ograničenje odnosi na izostanak analize o obilježjima nastave s obzirom na veličinu studijskih, nastavnih grupa studenata.

\section{Zaključak}

Visokoškolska umjetnička nastava uvelike je zanemarena u istraživanjima. Dok o poučavanju i primjeni metoda i strategija rada u nastavi znanstvenog područja postoji brojna literatura te se na taj način mogu pratiti razvojne tendencije i koncepcije poučavanja, a kroz njih i problemi u realizaciji, za nastavu umjetničkog područja svi aspekti poučavanja isključivo pripadaju sferi pojedine metodike. Primjetno je da u umjetničkoj nastavi postoji određena terminološka nedosljednost u korištenju didaktičkih pojmova koja zahtijeva žurnu razradu. Visokoškolska umjetnička nastava preuzela je tradicionalno prisutnu didaktičku 
nomenklaturu prikladniju oblikovanju nastave u znanstvenom području, prilagodivši ju pritom svojim specifičnostima. Takav pristup posljedica je višegodišnjeg prilagođavanja umjetničke nastave znanstveno orijentiranom visokoškolskom sustavu u kojemu je postalo prihvatljivije da se različiti obrazovni procesi nazivaju istim imenima, a izvode u potpunosti različito, nego da se ta različitost istraži i prizna. Umjetničkoj je nastavi potrebno didaktičko redefiniranje koje bi se istaknulo i objasnilo specifičnosti koje proizlaze iz prirode umjetničkog procesa i povezane su sa specifičnostima svakog pojedinog umjetničkog polja. Već samo terminološko definiranje kategorija kolegija na umjetničkim studijima na ranije navedene četiri osnovne kategorije, a prema kojem umjetnički kolegiji ili umjetnički radovi nisu stručni ni praktični nego umjetnički, ukazuje na to u kojem bi smjeru takvo didaktičko strukturiranje trebalo ići.

Iz rezultata istraživanja, koje je obuhvatilo nastavnike institucije na kojoj se ravnopravno izvode studijski programi iz dva znanstvena područja (društveno i humanističko) te iz četiri umjetnička polja (glazbena, kazališna, likovna i primijenjena umjetnost), bilo je moguće uočiti koji su to elementi koji se razlikuju u odnosu na oblikovanje nastavnoga procesa u različitim područjima. Razvidno je da je nastava oblikovana na suvremenim didaktičkim načelima aktivnog odnosa studenata prema nastavnom sadržaju, da su procesi poučavanja u umjetnosti često individualizirani, a praćenje rada i vrednovanje napretka studenata kontinuirano. Nastavnici koriste specifične nastavne aktivnosti kao što su stvaranje - umjetnička kreacija, uvježbavanje i praktični rad, ali se te metode i oblici u izvedbi znatno razlikuju. Istraživanje je pokazalo da se potencijal umjetničkog istraživanja kao oblik nastavnoga rada nedovoljno koristi u glazbenoj i likovnoj umjetnosti, dok je ono prisutnije u kazališnoj i primijenjenoj umjetnosti. Slično je i s metodom rada na tekstu, pri čemu bi se u različitim umjetnostima tekst trebao tretirati različito. Uvježbavanje je nastavna aktivnost karakteristična za sva polja umjetnosti te bi u budućim istraživanjima valjalo dodatno istražiti potencijal i implikacije koje proizlaze iz djelotvorne mentorske i samostalne primjene. Iako je iz odgovora nastavnika uočeno, kroz njihove različite odabire nastavne metode koje koriste, da oni podrazumijevaju raznovrsne situacije u poučavanju i načine aktiviranja studenata za ostvarivanje ciljeva te da su svjesni potrebe korištenja različitih načina 
prenošenja znanja, razvidna je terminološka nedosljednost, ali i pojmovna dualnost. Iz rezultata je utvrđeno da su svi nastavnici svjesni potrebe obogaćivanja nastavničkih znanja, a posebice je razvidan velik prostor koji se odnosi na osnaživanje nastavnika s informatičko-digitalnim kompetencijama.

Dobiveni rezultati otvaraju uvid u neke od prednosti i nedostatke umjetničke visokoškolske nastave te mogu doprinijeti budućem vrednovanju, planiranju i sistematiziranju nastavnoga rada na umjetničkim fakultetima, osobito u dijelu koji se odnosi na normiranje rada nastavnika, organizaciju nastave, vrednovanje kvalitete nastavnog procesa te ocjenjivanje studentskih postignuća. Osobito vrijedan doprinos očituje se u činjenici da rezultati istraživanja mogu poslužiti kao osnova u planiranju, razvijanju i akreditiranju novih studijskih programa u području umjetnosti, kao i za reviziju aktualnih i to prema kriterijima koji podjednako zadovoljavaju postojeći sustav visokog obrazovanja i karakteristika su svake umjetničke struke. Zaključci ukazuju na potrebu tipološkog definiranja specifičnih strategija, metoda i oblika umjetničko-nastavnog rada s ciljem unaprjeđenja cjelokupnog nastavnog procesa. Sustav vrednovanja i provjere studentskih postignuća također je moguće dodatno razraditi i uskladiti s funkcionalnom odnosno procesnom usmjerenošću umjetničke nastave kako bi u potpunosti održavao razinu realizacije ishoda učenja.

Nadamo se da će ovo istraživanje biti poticaj u oblikovanju suvremeno utemeljene didaktike, usmjerene prema didaktičkom strukturiranju nastave umjetničkog područja, a koja će biti kvalitetna teorijska osnova za poučavanje na specifičnim visokoškolskim ustanovama.

\section{Literatura}

Ball, Deborah L.; Forzani, Francesca M. (2009), »The work of teaching and the challenge for teacher education«, Journal of Teacher Education, 60(5), str. 497-511. doi: https://doi.org/10.1177/0022487109348479

Beard, Colin; McPherson, Maggie (2001), Design and Use of Group-based Training Methods, London: Human Resource Development Kogan Page.

Biggs, John (2003), »Aligning teaching for constructing learning «, Review of Higher Education, 1, str. 5-22.

Bognar, Ladislav; Matijević, Milan (2002), Didaktika, Zagreb: Školska knjiga. 
Borić, Edita (2013), Metodika visokoškolske nastave, Osijek: Sveučilište Josipa Jurja Strossmayera u Osijeku, Učiteljski fakultet u Osijeku.

Brust Nemet, Maja; Sili, Andrijana (2016), »Učiteljeve didaktičko-metodičke kompetencije za učinkovitu nastavnu komunikaciju«, Život i škola, 62(3), str. $163-172$.

Buljubašić-Kuzmanović, Vesna (2002), »Kvalitativno i kvantitativno vrjednovanje odgojno-obrazovnog procesa«, u: Vrgoč, Hrvoje (ur.), Praćenje i ocjenjivanje školskog uspjeha, Zagreb: Hrvatsko pedagoški književni zbor, str. 85-90.

Buljubašić-Kuzmanović, Vesna (2003), »Kooperativno učenje u nastavi kao čimbenik socijalizacije«, Napredak, 144(4), str. 459-473.

Burn, Katharine; Hagger, Hazel; Mutton, Trevor; Everton, Tim (2003), »The complex development of student-teachers' thinking «, Teachers and Teaching: Theory and Practice, 9(4), str. 309-331. doi: https://doi.org/10.1080/13540 $\underline{60032000097235}$

Clark, Donald (2009), Visual, Auditory, and Kinesthetic Learning Styles (VAK), London: Don Clark Production.

Conway, Paul F.; Clark, Christopher M. (2003), »The journey inward and outward: A reexamination of Fuller's concerns-based model of teacher development «, Teaching and Teacher Education, 19(5), str. 465-482. doi: https://doi. org/10.1016/S0742-051X(03)00046-5

Curtis, Will W. (2012), »Filozofija odgoja«, u: Duffour, Barry; Curtis, Will W. (ur.), Studij odgojno-obrazovnih znanosti, Zagreb: Educa, str. 71-98.

Cvejić, Biserka; Cvejić, Dušan (2009), Umetnost pevanja, Beograd: IP Signature.

Feyerabend, Paul (2010), Against Method, Fourth Edition, London, New York: Verso.

Gospić Županović, Ana (2016), »Naslijeđe Stanislavskog u radu Grotowskog: O značenju metode fizičkih radnji«, SIC: časopis za književnost, kulturu i književno prevođenje, 7(1), str. 1-25. doi: https://doi.org/10.15291/sic/1.7.lc.5

Hannula, Mika; Suoranta, Juha; Vadén, Tere (2014), Artistic Research Methodology. Narrative, Power and the Public, Frankfurt am Main: Peter Lang Inc., International Academic Publishers. doi: https://doi.org/10.3726/978-1-45391308-6

Hercigonja, Zoran (2018), »Kompetencije nastavnika i učenika u postizanju optimalnoga obrazovanja«, Zbornik radova Međimurskog veleučilišta u Čakovcu, 9(1), str. 22-30.

Hewitt, Des (2003), Understanding Effective Learning. Strategies for the Classroom, Glasgow: Bell and Bain Ltd.

Jensen, Annie Aarup; Stentoft, Diana; Ravn, Ole (2019), Interdisciplinarity and Problem-Based Learning in Higher Education, Springer Nature Switzerland. doi: https://doi.org/10.1007/978-3-030-18842-9

Jerković, Berislav (2019), Kurikul nastave pjevanja, Osijek: Akademija za umjetnost i kulturu u Osijeku. 
Jurčić, Marko (2014), »Kompetentnost nastavnika - pedagoške i didaktičke dimenzije «, Pedagogijska istraživanja, 11(1), str. 77-93.

Kline, Rex B. (2005), Principles and Practice of Structural Equation Modeling (2nd ed.). New York: Guilford Press.

Knight, Peter (1995), Assessment for Learning in Higher Education, London: SEDA and Kogan Page.

Mužić, Vladimir (1999), Uvod u metodologiju istraživanja odgoja i obrazovanja, Zagreb: Educa.

Nikčević-Milković, Anela (2004), »Aktivno učenje na visokoškolskoj razini«, Život i škola, 12(2), str. 47-54.

Novković Cvetković; Biljana; Stošić, Lazar; Beleusove, Alla (2018), »Media and information literacy-the basis for applying digital technologies in teaching from discourse of educational needs of teachers «, Croatian Journal of Education, 20(4), str. 1089-1114. doi: https://doi.org/10.15516/cje.v20i4.3001

Peko, Anđelka; Mlinarević, Vesnica (2012), »Didaktičke kompetencije visokoškolskih nastavnika u konceptu cjeloživotnog obrazovanja«, Evkönyv, 6(1), str. $65-75$.

Peko, Anđelka; Mlinarević, Vesnica; Buljubašić-Kuzmanović, Vesna (2008), »Potreba unaprjeđivanja sveučilišne nastave«, Odgojne znanosti, 10(1), str. 195-208.

Postupak inicijalne akreditacije za izvođenje studijskih programa - pročišćeni tekst (2017), Zagreb: Agencija za znanost i visoko obrazovanje.

Raja, R., Nagasubramani, P. C. (2018), »Impact of modern technology in education«, Journal of Applied and Advanced Research, 3(1), str. 33-35. doi: https:// doi.org/10.21839/jaar.2018.v3iS1.165

Raponja, Robert (2018), Pisma studentima, Osijek: Akademija za umjetnost i kulturu u Osijeku.

Rolheiser, Carol; Bower, Barbara; Stevahn, Laurie (2000), The Portfolio organizer. Succeeding with Portfolio in Your Classroom. Alexandria, Virginia: Association for Supervision and Curriculum Development.

Stefani, Lorraine; Mason, Robin; Pegler, Chris (2007), The Educational Potential of e-Portfolios. Supporting Personal Development and Reflective Learning, London, New York: Routledge. doi: https://doi.org/10.4324/9780203961292

Stjepanović, Boro (2013), Gluma I. / Rad na sebi, Osijek: Umjetnička akademija u Osijeku.

Strategija obrazovanja, znanosti i tehnologije (2014), Zagreb: NN, br. 124, Hrvatski sabor Republike Hrvatske.

Strategija Sveučilišta Josipa Jurja Strossmayera u Osijeku (2011), Osijek: Sveučilište Josipa Jurja Strossmayera u Osijeku.

Škojo, Tihana (2016), »Nastava glazbene umjetnosti u kontekstu aktivnog učenja«, Śkolski vjesnik: časopis za pedagogiju i praksu, 65(2), str. 229-250. 
Treffinger, Donald J.; Young, Grover C.; Selbi, Edwin C.; Shepardson, Cindy (2002), Assesing Creativity: A Guide for Educators, Sarasota/Florida: Center for Creative learning.

Vennard, Wiliam (1967), Singing: The Mechanism and the Technic, New York: Carl Fisher, Inc.

\title{
ANALYSIS OF THE USE OF TEACHING STRATEGIES IN HIGHER EDUCATION IN ARTS
}

\author{
Antoaneta Radočaj-Jerković, Tihana Škojo
}

The paper presents the research that analysed the use of the teaching strategies - methods and procedures, teaching methods, and evaluation of students' achievements - at one public art university in Croatia. The results show that the higher education in arts is based on contemporary didactic principles with a dominant paradigm of student-centered learning. Accordingly, students are encouraged to take an active role in the learning process, procedures of teaching arts are individualized, and monitoring the work and evaluating student progress is done systematically. However, there is a certain terminological inconsistency in the use of some didactic terms in teaching of art, since teaching art in higher education has appropriated the traditional didactic nomenclature, more suitable for teaching science. Through obtained results, the need for a conceptual redefinition was discovered, in which the specifics arising from the nature of artistic process, related to the specifics of individual artistic fields, would be emphasized and explained. The results show both positive and negative aspects of the current art teaching in higher education. The results of this research can contribute to better understanding of the art teaching as well as to the future systematization of teaching work at art faculties, especially in the part related to organization and evaluation of the teaching process.

Keywords: teaching strategies of art teaching, university teachers, higher education art teaching 